Rozprawy Komisji Językowej ŁTN, t. LXVII, 2019

ISSN 0076-0390; e-ISSN 2450-9310

https://doi.org/10.26485/RKJ/2019/67/8

Marzena Guz*

(D) https://orcid.org/0000-0003-4630-2584

\title{
NIEMIECKIE SLOWNICTWO MARYNISTYCZNE W PUBLIKACJI MARITIMES WÖRTERBUCH JÜRGENA GEBAUERA I EGONA KRENZA. WYBRANE ZAGADNIENIA
}

\author{
GERMAN MARITIME VOCABULARY IN THE PUBLICATION, \\ MARITIMES WÖRTERBUCH BY JÜRGEN GEBAUER \\ AND EGON KRENZ. SELECTED QUESTIONS
}

This article discusses German maritime vocabulary in terms of word formation, onomastics, borrowing and sailing jargon.

Keywords: vocabulary, German language, sailing language, word formation, onomastics

Słowa kluczowe: słownictwo, język niemiecki, język marynarski, słowotwórstwo, onomastyka

\section{WPROWADZENIE}

Język marynarski należy, obok języka górniczego, do najstarszych języków specjalistycznych w Niemczech [Lisiecka-Czop, 2010, s. 42]. Słownictwu temu poświęcono dotąd cztery monografie w języku polskim [Łuczyński, 1986; 1987; Ożdżyński, 1989; Kołodziejek, 1994]. Ukazał się także dziesięciojęzyczny Słownik żeglarski [por. Webb, 2012]. W 2017 roku odbyła się konferencja na temat morskich kontaktów językowych i morskiej leksykografii, zorganizowana przez Instytut Filologii Germańskiej Wydział Filologiczny Uniwersytetu Szczecińskiego oraz Książnicę Pomorską. Rok później pojawiła się publikacja, która zawiera między innymi dziewięć artykułów z tego wydarzenia [np. Kramer, 2018; Lipczuk,

* Uniwersytet Warmińsko-Mazurski w Olsztynie, Wydział Humanistyczny, Katedra Filologii Germańskiej, ul. Obitza 1, 10-725 Olsztyn; e-mail: marzgu@op.pl. 
Sztandarska, 2018; Szczaus, 2018]. Żywiołom występującym w słownictwie żeglarskim przyjrzała się w swoim artykule Maria Lesz-Duk [2017, s. 225-235].

Celem niniejszego artykułu jest analiza językowa słownictwa marynistycznego. W pierwszym rzędzie zostaną omówione zagadnienia morfologiczne, tzn. słowotwórstwo rzeczowników (bogactwo rzeczowników złożonych oraz derywaty), czasowników i przymiotników. Następnie poruszony zostanie problem składni, a dokładniej wielu rodzajów przydawek. Materiał badawczy zostanie omówiony także pod kątem onomastyki. W opisywanym słownictwie mamy do czynienia również z zapożyczeniami i wyrazami obcymi, na przykład anglicyzmami, galicyzmami, hispanizmami oraz ze słownictwem rosyjskim. Ponieważ wiadomo, że język marynarzy w dużej mierze opiera się na słownictwie obcym, a nie sposób zmieścić w wąskich ramach tego artykułu wnikliwej analizy ilościowej, autorka ogranicza się jedynie do zasygnalizowania problemu obecności zapożyczeń. W słowniku znajdują się także liczne słowa i zwroty pochodzące z żargonu żeglarskiego. Ciekawym zjawiskiem jest występowanie metafor genetycznych. W opracowaniu chodzi o zasygnalizowanie powyższych zagadnien, oparte na subiektywnie wybranych przykładach.

Materiał badawczy pochodzi ze słownika marynistycznego w języku niemieckim pt. Maritimes Wörterbuch, autorstwa Jürgena Gebauera i Egona Krenza, wydanego w 1989 roku w Berlinie nakładem Militärverlag der Deutschen Demokratischen Republik. W nawiasach podano numery stron z wyżej wymienionego słownika. W opracowaniu tym, liczącym 304 strony, występują liczne zdjęcia, rysunki i schematy, a układ haseł jest alfabetyczny.

\section{MORFOLOGIA}

Najczęstsze wśród haseł są oczywiście rzeczowniki, rzadziej można spotkać czasowniki, np.: gieren (s. 81), glasen (s. 82), zurren (s. 301). Jeszcze rzadziej niż czasowniki występują przymiotniki, np. luvgierig (s. 138). Nieliczne są również przysłówki, np. dwars (s. 51).

\subsection{Słowotwórstwo}

\subsubsection{Rzeczownik}

Bardzo licznie występują dwuczłonowe złożenia rzeczownikowe, nieco rzadszym zjawiskiem są złożenia trójczłonowe, np.: Alle-Manns-Manöver (s. 12), Defensivminensperre (s. 46), Doggerbankgefecht (s. 49), Leicht-Schnellboot (s. 129). Niektóre z nich występują z dywizem. Do compositów czteroczłonowych zaliczają się np.: Mehrzweckkampfschiff(s. 13), Elektrodenfernräumgerät (s. 53). 
W badanym słowniku przyciagają uwagę liczne złożenia $\mathrm{z}$ tym samym członem, np.:

1) Anker 'kotwica' jako pierwszy człon złożenia (s. 14-15), np.: Ankerball, Ankerboje, Ankergeschirr 'ogół urządzeń i mechanizmów służących do opuszczenia kotwicy' ', Ankerkette 'łańcuch kotwicy', Ankerspill, Ankerwinde 'winda kotwiczna' i złożenie z trzech członów: Ankertaumine 'mina morska';

2) Anker 'kotwica' jako drugi człon złożenia, np.: Admiralitätsanker (s. 11), Eisanker (s. 52), Hallanker (s. 85), Stockanker (s. 250), Normalanker (s. 250), Pilzanker (s. 174);

3) Artillerie jako pierwszy człon złożenia (s. 18), np.: Artillerieleichter, Artillerieschiff, Artillerieträger oraz złożenia z trzech członów: Artilleriefährprahm, Artillerieschnellboot;

4) Gefecht 'bój, walka' (s. 74-77), 14 złożeń z tym słowem w pierwszym członie, np.: Gefechtsabschnitt, Gefechtsalarm, Gefechtsausbildung, Gefechtsbereitschaft 'gotowość bojowa', Gefechtsberührung, Gefechtsformation, Gefechtskurs, Gefechtsordnung 'szyk bojowy'; Gefecht jako drugi człon złożenia występuje w wyrazie Seegefecht 'potyczka morska'.

Liczne złożenia tworzą też:

1) Torpedo: 10 compositów (s. 257-260), np.: Torpedoboot 'kuter torpedowy'; niektóre z nich składają się z trzech członów, np.: Torpedofangboot, Torpedonetzsperre, Torpedoschnellboot, Torpedotransportschiff, a nawet z czterech członów: Torpedowaffenleitanlage; wśród wymienionych formacji słowotwórczych znalazła się para synonimów: Torpedoboot - Torpedobootszerstörer 'torpedowce'; charakterystyczne dla socjolektów jest występowanie rozbudowanej synonimiki [por. Sors, 2013, s. 122];

2) U-Boot 'łódź podwodna' to derywat, skrótowiec od Unterseeboot: 24 composita (s. 269-275), np.: U-Boot-Abwehr 'obrona przeciw okrętom podwodnym', o trzech złożeniach: U-Boot-Abwehr-Rakete, o czterech członach: U-Boot-Abwehr-Fliegerkräfte;

3) Unterwasser 'podwodny', np.: 6 compositów (s. 277-279), np.: Unterwasserkräfte, Unterwasserlage (dwa człony), Unterwasser-Raketenstart (trzy człony, człon po dywizie składa się z dwóch członów), Unterwasser-Kleinkampfmittel

1 Odpowiedniki lub wyjaśnienia w języku polskim nie są podawane w artykule w każdym przypadku.

2 Zapis z dywizem, ponieważ w tym przypadku ten człon nie jest samodzielnym rzeczownikiem ani inną częścią mowy. Notowany w Wielkim słowniku niemiecko-polskim wyraz Unterwasser ma znaczenie 'woda zaskórna', które nie koresponduje ze znaczeniami omawianych tu haseł zaczynających się od tego członu. 
'najmniejsze łodzie podwodne' (cztery człony, ponieważ człon po łączniku jest złożeniem zawierającym aż trzy człony).

Derywaty rzeczownikowe są bardzo rzadkie, np. Aufkimmung (s. 20).

\subsubsection{Czasownik}

\section{Derywaty prefiksalne}

W słowniku warto zwrócić uwagę na dużą liczbę czasowników z przedrostkiem ab-: abarbeiten, abbacken, abbäumen, abbergen, abblasen, abblenden, abbringen, abdrehen, abfallen, abgreifen, ablaufen, ablegen, abreiten, abschaken, abscheren, abschlagen, abschleppen, abschlingen, abschricken, absetzen, abslippen, abstechen, abstoppen, abtakeln, abwettern, abwracken. Jest ich aż 26. Niektóre z nich to derywaty odrzeczownikowe: abbäumen od der Baum 'drzewo', abwettern od das Wetter 'pogoda'3 abwracken od das Wrack 'wrak'. Liczne są też czasowniki z przedrostkiem auf-: aufbacken, aufbringen, aufdampfen, aufgrehen, aufduven, auffangen, aufffieren, aufgeien, aufheißen, aufholen, aufklaren, aufkommen, auflaufen, auflegen, aufpalmen, aufpicken, aufrichten, aufschießen, aufschlagen, aufslippen, aufsorren, auftakeln, auftoppen, auftuchen (24 czasowniki).

Kilka czasowników ma przedrostek an-, np.: anlanden, anlaufen, anliegen, anluven, anpreien, anreihen. Słownik rejestruje 16 czasowników z przedrostkiem aus-, np.: ausbooten od rzeczownika Boot 'łódź', co oznacza 'dostarczyć coś łodziami na ląd'.

Czasowniki z przedrostkami bei-: beidrehen, beiliegen, durch-: durchholen oraz vor: vorheißen mają niską frekwencję w słowniku marynistycznym.

Interesujące jest to, że słownik nie rejestruje żadnego czasownika z przedrostkami hin-, mit-, über-, um- oraz zu-.

Złożenia czasownikowe, np. achteraussegeln ${ }^{4}$ (s. 10), dichtholen (s. 47), dichtsetzen (s. 47). Podane przykłady mają strukturę przymiotnik + czasownik.

\subsubsection{Przymiotnik i przysłówek}

Złożenia przymiotnikowe, np. achterlastig (s. 10), auflandig (s. 21), vierkant 'prostokątny' (s. 282).

Złożenia przysłówkowe, np. achterhand (s. 10).

${ }^{3}$ O czasownikach pochodzących od rzeczowników z kręgu tematycznego natura pisała między innymi Marzena Guz [2006, s. 195-206].

4 Achter 'tylny'. 


\section{SKLADNIA}

\section{Rzeczowniki z przydawkami:}

1) z przydawką przymiotnikową ${ }^{5}$, np.: akustische Seemine (s. 11), hohle See (s. 92); Internationales Signalbuch (s. 95); częstą przydawką przymiotnikową w badanym materiale jest amphibisch: amphibische Kräfte (s. 13), amphibischer Hubschrauberträger (s. 13), amphibisches Mehrzweckkampfschiff (s. 13);

2) $\mathrm{z}$ dwiema przydawkami przymiotnikowymi, np.: absenkabare hydroakustische Anlagen (s. 8);

3) z przydawką w formie imiesłowu czynnego, np.: treibende Seemine (s. 262), Diensthabendes Schiff (s. 47), fahrendes Personal (s. 55);

4) z przydawką w formie imiesłowu biernego, np.: bordgestützte Fliegerkräfte (s. 34);

5) z przydawką dopełniaczowa, np.: Basierungssystem der Flotte (s. 28), Dicke eines Taus (s. 47), Eisfahrt der Baltischen Flotte 1918 (s. 52);

6) z przydawką przyimkową, np.: Dienst an Bord (s. 47).

\section{ONOMASTYKA}

\section{Eponimy}

W badanym materiale występują złożenia rzeczownikowe zawierające nazwy własne i derywaty wywodzące się od nazw własnych. Tego typu złożenia należą głównie do słownictwa technicznego [Fleischer, Barz, 2007, s. 134]. Do nautycznych przykładów należą np.: Beaufort-Skala (s. 29), Voith-Schneider-Propeller (s. 282).

Congrevsche Rakete 'rakieta zaprojektowana przez Williama Congreve'a' (s. 42) to przykład derywatu utworzonego od nazwiska [por. Fleischer, 1992, s. 58].

W przykładzie Achtersteven '1. tylna część kadłuba statku, 2. żartobliwe określenie tylnej części ciała’ (s. 10) - mamy do czynienia z apelatywizacją drugiego, imiennego członu złożenia. Zaszła ona przez semantyczne uogólnienie męskiego imienia Steven jako drugiego członu. Zapelatywizowane imię oznacza osobę i do tego wywołuje negatywną konotację [Fleischer, Barz, 2007, s. 135].

Do eponimów odtoponimicznych [por. Harnisch, Nübling, 2004, s. 1908] należy pojęcie Dardanellen-Operation (s. 44).

Wśród eponimów przeważają composita z bazą apelatywną i dywizem. Derywaty od nazwisk zawieraja podstawy o specyficznej referencji i tym samym

\footnotetext{
5 Na temat tej przydawki pisała między innymi Marzena Guz [2014, s. 82-84].
} 
wyrażają relacje względem czegoś (a nie właściwości). Często powiązane są z kontekstem sytuacyjnym [Kempf, 2016, s. 112].

Eponimy rzadko występują jako wyrazy niederywowane, np.: Davit (s. 45) - $\mathrm{z}$ angielskiego davit, prawdopodobnie od imienia Dawid 'podnośnik do kotwicy, łodzi ratunkowych' [Duden, 1996, s. 321].

\section{Kryptonimy}

Kryptonimy to litery i cyfry albo wyrazy ukrywające właściwą nazwę czegoś lub czyjeś nazwisko [https://sjp.pwn.pl/sjp/kryptonim;2565035.html]. Pierwsze nazwy operacji wojskowych powstały w niemieckim sztabie generalnym w ostatnich dwóch latach I wojny światowej. Niemcy zaczęli używać kryptonimów przede wszystkim ze względu na tajność, ale również praktyczność - krótka i łatwa do zapamiętania nazwa umożliwiała łatwiejszą komunikację z podwładnymi. Nie bez powodu początek wykorzystywania kryptonimów pokrywa się z rozwojem sztuki operacyjnej. Niemcy wybierali nazwy, które były nie tylko łatwe do zapamiętania, ale także inspirowały. Przykładowo: plany operacji wielkiej ofensywy na froncie zachodnim wiosną 1918 roku miały kryptonimy zapożyczone ze źródeł religijnych, średniowiecznych i mitologicznych [Curda, 2017].

Przykłady kryptonimów z badanego materiału to: Catapult: z języka łacińskiego catapulta, a to z języka greckiego katapèltēs 'katapulta' [Duden, 1996, s. 820] - kryptonim operacji brytyjskiej floty wojennej mającej na celu zniszczenie francuskiej marynarki wojennej w lipcu 1940 roku (s. 39), Chariot: z angielskiego 'rydwan' [Linde-Usiekniewicz, 2007, s. 192] - kryptonim akcji brytyjskich komandosów w rejonie portu we francuskim mieście Saint-Nazaire w marcu 1942 roku (s. 40), Deadlight: z angielskiego 'śmiertelny ogień' - określenie akcji zatapiania niemieckich łodzi podwodnych przez brytyjską flotę wojenną od listopada 1945 do stycznia 1946 roku (s. 45), Zerberus: kryptonim operacji przebicia się okrętów niemieckiej marynarki wojennej przez kanał La Manche w lutym 1942 roku (s. 297), Zitronella: kryptonim operacji niemieckiej marynarki wojennej na Spitsbergenie we wrześniu 1943 roku (s. 299).

\section{Nazwy wydarzeń historycznych}

Nazwy te określane są także jako historyczne nazwy własne [Maziarz, 2012, s. 27-33]. Marynistyczne przykłady to między innymi: Cattaro $^{6}$ (miejsce wybuchu powstania marynarzy w 1918 roku) (s. 40), Coronel 1914 (miejsce potyczki morskiej u wybrzeża Chile) (s. 42), Dieppe 1942 (desant w rejonie miasteczka Dieppe w Górnej Normandii, przeprowadzony przez sprzymierzonych) (s. 48), Falkland-

\footnotetext{
${ }^{6}$ Kotor w Czarnogórze - miasto portowe na wybrzeżu Adriatyku.
} 
-Inseln 1914 (bitwa morska) (s. 56), Marloh-Mord (mord na marynarzach w Berlinie w 1919 roku; Marloh to nazwisko porucznika, który wydał rozkaz ich rozstrzelania) (s. 143), Trafalgar 1805 (bitwa morska na przylądku Trafalgar) (s. 260).

Powyższe nazwy składają się tylko z nazwy geograficznej albo z nazwy geograficznej i roku wydarzenia, rzadko są to złożenia zawierające nazwisko jako pierwszy człon.

\section{Ergonimy}

Ergonimy to nazwy instytucji [por. Debus, 2012, s. 195; Eckkrammer, Thaler, 2013, s. 7]. Przykłady z badanego materiału to: Deutscher Flottenverein (s. 46), Hanse (s. 86).

\section{ZAPOŻYCZENIA I SLOWNICTWO OBCE}

Zapożyczenia stanowią znaczną część słownictwa gwary środowiskowej marynarzy, ponieważ specyfika ich zawodu polega między innymi na wykonywaniu go poza granicami kraju [Kołodziejek, 1994, s. 109]. W języku potocznym marynarzy zapożyczenia występują w słownictwie służącym porozumiewaniu się oraz wyrażaniu emocji [Kołodziejek, 1994, s. 110].

Terminologia marynistyczna powstała w późnym średniowieczu na ogólnogermańskim podłożu, następnie wzbogaciły ją włoskie, arabskie i hiszpańskie wpływy [Schmidt, 1984, s. 94; Lisiecka-Czop, 2010, s. 42]. Inne źródła mówia, iż słownictwo nautyczne bierze początek z języka średnio-dolno-niemieckiego, który pozostawał pod wpływem języków niderlandzkiego i angielskiego [Opitz, 1998, s. 1211-1212; Lisiecka-Czop, 2010, s. 42].

\section{Zapożyczenia niderlandzkie}

Ruchy migracyjne Holendrów w południowo-wschodnie rejony Bałtyku, wielonarodowościowy skład załóg okrętów oraz czynniki komunikacyjne przemawiają za uwzględnieniem bezpośrednich wpływów holenderskich [Zabrocki, 1956, s. 156, 172; Ożdżyński, 1989, s. 78]. Przykłady zapożyczeń niderlandzkich w badanym słowniku to: Barkasse (s. 28) [Duden, 1996, s. 208], Besan (s. 34) [Duden, 1996, s. 239], Bram (s. 36) [Duden, 1996, s. 279], Gillung (s. 82) [Duden, 1996, s. 611], Gösch (s. 83) [Duden, 1996, s. 623], Havarie (s. 88) [Duden, 1996, s. 675], Kai (s. 99) [Duden, 1996, s. 798], Kaper (s. 104) [Duden, 1996, s. 809].

\section{Anglicyzmy}

Przeglądając badany słownik, wydaje się, że wiele pożyczek z języka angielskiego jest w powszechnym użyciu. Jednak ze względu na szczupłe ramy 
niniejszego opracowania wymieniam tylko kilka przykładów: dippen, w wyrażeniu Flagge dippen (s. 49, 62), z angielskiego dip [Duden, 1996, s. 347], 'opuszczenie flagi' (s. 62), Dreadnought 'nazwa brytyjskiego statku' (s. 50), $X$-crafts 'najmniejsze łodzie podwodne podczas II wojny światowej w Wielkiej Brytanii' (s. 296).

\section{Galicyzmy}

W badanym materiale rzadko można spotkać pożyczki z języka francuskiego: Bonnet (s. 33) ${ }^{7}$, Deplacement (s. 46) - z języka francuskiego deplacèment 'budowa statków' [Duden, 1996, s. 332], Korvette (s. 114) [Duden, 1996, s. 887].

\section{Hispanizmy}

Podobnie rzadko jak galicyzmy występują zapożyczenia z języka hiszpańskiego: Armada (s. 17) [Duden, 1996: 141], Flotille (s. 66) [Pfeifer, 1997, s. 359].

\section{Hybrydy słowotwórcze}

W badanym materiale występują obcojęzyczne komponenty złożeń [Burkacka, 2010, s. 234], pochodzące na przykład z języków francuskiego, angielskiego, niderlandzkiego oraz greckiego, co ilustrują następujące przykłady: Gefechtsloxodrome (s. 76), Loxodrome z języka greckiego [Duden, 1996, s. 968]; Kartellschiff (s. 105), Kartell to adaptacja ${ }^{8}$ francuskiego cartel [Duden, 1996, s. 816]; Kasemattschiff (s. 105), Kasematt to adaptacja francuskiego casemate [Duden, 1996, s. 818]; Kasernenschiff (s. 106), Kaserne to adaptacja francuskiego caserne [Duden, 1996, s. 818]; Klüverbaum (s. 110), Klüver to adaptacja z dawnego niderlandzkiego kluver [Duden, 1996, s. 849]; Laser-Ortungsgerät, Laser-Waffenleitsystem (s. 127), Laser to pożyczka z języka angielskiego [Duden, 1996, s. 928]; Lazarettschiff (s. 128), Lazarett to adaptacja z francuskiego lazaret [Duden, 1996, s. 934]. Jak wskazuje podany wyżej materiał hybrydy w omawianym słowniku są nie tylko dwu-, ale i trój- oraz czteroczłonowe.

\section{Slownictwo rosyjskie}

Słownictwo rosyjskie występuje rzadko, a jeśli już - to w postaci nazw własnych lub chrematonimów jako hasło w słowniku i/lub jako opis zdjęcia, np. AURORA - nazwa legendarnego statku radzieckiej marynarki wojennej (s. 22). Na potrzeby niniejszego artykułu w opisach zamieszczonych w słowniku zdjęć wytłuszczono rosyjskie nazwy, np.: Das Wachschiff BOEWOI der

7 Inne niż marynistyczne znaczenie w Duden [1996, s. 275].

8 Przykład hybrydy z zaadaptowanym wyrazem obcym podaje Iwona Burkacka [2010, s. 30-231]. 
Baltischen Rotbannerflotte der UdSSR ${ }^{9}$ (s. 27) - nazwa okrętu; Flugdeckschiff KIEW der Seekriegsflotte der UdSSR (s. 67) - nazwa geograficzna jako nazwa okrętu; Kernkraftgetriebener sowjetischer Raketenkreuzer KIROW (sic) (s. 107) - nazwisko jako nazwa krążownika rakietowego; Sowjetischer 17 200-ts-Artilleriekreuzer vom Typ Swerdlow (s. 19) - nazwisko jako nazwa typu krążownika artyleryjskiego.

Jako hasło występuje w słowniku nazwa krążownika pancernego Potjomkin (s. 175), utworzona od nazwiska księcia. Podczas rewolucji 1905 roku na tym statku wybuchło powstanie marynarzy.

\section{FACHOWY JĘZYK MARYNARSKI I ŻARGON}

W językach fachowych wyróżnia się terminologię i żargon. Uwagę przyciagają głównie nieznane wyrazy. Dla specjalistów w danej dziedzinie nie stanowią one problemu, laikom wydają się zaś zbyteczne i sztuczne [Kaube, 2012, s. 105].

Jedną z cech żargonu jest skrótowość. W trakcie wykonywania profesjonalnej czynności wystarczy zasygnalizować treść komunikatu niepełnym wyrazem lub fragmentem dłuższego wypowiedzenia [Grabias, 1997, s. 147]. Słownictwo marynarskie odznacza się wysokim stopniem zawodowości [Grabias, 1997, s. 149]. W socjolekcie tym dominuje ponadto kategoria ekspresywności [Sors, 2013, s. 127], a język fachowy często miesza się z żargonem [Schlaefer, 2009, s. 50].

Przykłady rzeczowników w żargonie: Aal 'torpeda' (s. 7), Gamel 'coś nieporządnego' (s. 73), Gammelpäckchen 'bumelant' (s. 73), Mist 'mgła' (s. 154), Wuling 'bałagan, natłok' (s. 296).

Przykład czasownika w żargonie: aufschießen 'unikanie pracy' (s. 21).

Zjawiska językowe, które odnotowano podczas analizy:

1) imiona jako pojęcia specjalistyczne: Diana 'dawniej bicie w bęben na okrętach wojennych przez straż dzienną' (s. 47); Dirk 'lina kotwiczna' (s. 49);

2) zwroty: an den Wind gehen (s. 13), aus dem Ruder laufen (s. 23), über Stag gehen (s. 266);

3) zwillingsformeln, czyli utarte zwroty bliźniacze - frazeologiczne pary wyrazów zbudowane są najczęściej z dwóch wyrazów połączonych spójnikami lub przyimkami [Tadeusz, Laskowski, 1994, s. 3]; przykłady z przeprowadzonej analizy: auf und nieder 'pionowo' (s. 22), Backen und Banken 'podawanie i spożywanie posiłków na pokładzie' (s. 25), Hand über Hand m.in. 'określenie

9 Skrót od Union der Sozialistischen Sowjetrepubliken (Związek Socjalistycznych Republik Radzieckich). 
stopniowo cichnącego sztormu' (s. 86), hoch und trocken 'osiadanie statku na mieliźnie' (s. 92).

\section{Komunikacja w języku żeglarskim}

Podstawowa funkcja języka w środowisku marynarzy to podporządkowanie go wymogom zawodu i charakterowi wykonywanej pracy. Warunki na morzu wymagają szybkich reakcji, dlatego polecenia muszą być wykonywane błyskawicznie, precyzyjnie i tak też odbierane.

Odciska to silne piętno na warstwie leksyki pełniącej funkcję komunikatywną, którą charakteryzuje zwięzłość, lakoniczność, lapidarność. Wypowiedzi formułowane są w formie komendy, rozkazu bądź meldunku [Kołodziejek, 1994, s. 46].

Z komend eliminowane są zbędne elementy językowe: czasowniki, przyimki, końcówki fleksyjne [Kołodziejek, 1994, s. 46].

Przykłady z przeprowadzonego badania:

1) komendy: Fall ins Boot (s. 59), Fest (s. 60),

2) zawołania: Besanschot an (s. 31),

3) ostrzeżenia: Abwärts (s. 9),

4) odpowiedzi: Alles wohl (s. 12).

W zebranym korpusie nie brakuje także słów ze standardowego języka niemieckiego, które zmieniły swoje znaczenie [Ammon, 1995, s. 480]. Tak więc pojęcia fachowe nie zawsze wyróżniają się swoją egzotyką [Kaube, 2012, s. 106]. Kilka przykładów z przeprowadzonego badania: arbeiten 'ruch statku na morzu' (s. 17), bergen '1. zwijanie żagli przed szturmem, 2. ratowanie statku będącego w zagrożeniu' (s. 31), brechen '1. uszkodzenie lin, 2. przybój fal' (s. 38), Deklination 'odchylenie igły magnetycznej' (s. 46), Deviation 'odchylenie igły magnetycznej pod wpływem żelaza i stali na okręcie' (s. 47), Evolution 'określony ruch statku' (s. 55). Ponadto występują złożenia z tego typu członami, np.: Derivationswinkel (s. 46).

Warto wspomnieć o metaforach genetycznych ${ }^{10}$. W analizowanym materiale można spotkać tego typu metafory, np.: Delphin m.in. 'w starożytności ciężki kawałek żelaza lub ołowiu w formie delfina' (s. 46), Hals 'szyja', m.in. 'druciana lina' (s. 85), Kleid 'suknia', 'rodzaj pokrowca na umieszczone na zewnątrz urządzenia, np. kompasy, reflektory’ (s. 109).

Interesujące $\mathrm{z}$ lingwistycznego punktu widzenia wydaje się występowanie wyrazów pochodnych od wspomnianych wyżej metafor, np. z metafory Hals powstał czasownik halsen (s. 85).

\footnotetext{
${ }^{10}$ Pisała o nich na przykład Marzena Guz [2018, s. 133-134].
} 
W analizowanym korpusie nie brak też fachowych compositów zmetaforyzowanych częściowo lub w całości [Fleischer, Barz, 2007, s. 99], np.: Bullauge, -auge 'oko', 'okragłe okno na statku, iluminator' (s. 39), Eselshaupt 'ośla głowa', 'kawałek twardego drewna jako łącznik' (s. 55), Augbolzen 'bolec z otworem' (s. 22), Außenhaut, -haut 'skóra', 'zewnętrzna ściana kadłuba statku' (s. 24), Düsenschanzkleid, -kleid 'suknia', 'konstrukcja służąca do ochrony personelu na mostku przed wiatrem' (s. 51). Wymienione metafory pochodzą z kręgów tematycznych „części ciała” oraz „odzież”.

\section{WNIOSKI}

W słowniku, podobnie jak w całym języku niemieckim, występuje bogactwo złożeń. Co ciekawe, niektóre wyrazy wyjątkowo często wchodzą w ich skład jako pierwszy człon. Najczęściej jednak występują formacje słowotwórcze z pierwszym członem - U-Boot 'łódź podwodna'. Uwagę przyciaga duża liczba czasowników z przyrostkami $a b$ - i auf-. W słowniku występuje wiele przydawek rzeczownikowych. W źródle, o którym mowa, odnotować można eponimy, kryptonimy, nazwy wydarzeń historycznych oraz ergonimy (nazwy instytucji). Wśród eponimów najwięcej jest złożeń, których bazę stanowi apelatyw. Zdarza się, że kryptonimy są pochodzenia angielskiego. Nazwy wydarzeń historycznych to same nazwy miejsc lub nazwy miejsc $\mathrm{z}$ dodaniem daty. Jeśli chodzi o zapożyczenia, to największą frekwencję wykazują pożyczki z języka niderlandzkiego oraz angielskiego. Częste są złożenia z obcym członem, np. z języka francuskiego. Słownictwo rosyjskie reprezentowane jest słabo. Żargon marynarski w nieznacznym tylko stopniu charakteryzuje się ekspresywnością.

W artykule zaprezentowano wybiórczo pewne zagadnienia z kręgu tytułowej problematyki, kierując się subiektywnymi kryteriami. Każde z poruszanych zagadnień, sygnalizowanych tytułami rozdziałów, wymaga osobnych studiów naukowych.

\section{BIBLIOGRAFIA}

Ammon Ulrich, 1995, Die deutsche Sprache in Deutschland, Österreich und der Schweiz. Das Problem der nationalen Varietäten, de Gruyter, Berlin-New York.

BURKACKA Iwona, 2010, Klasyfikacja słowotwórcza nowszych zapożyczeń, „Linguistica Copernicana”, t. 2(4), s. 229-240. 
CuRda Joseph, 2017, Stowa, które niosty śmierć - kryptonimy operacji wojskowych w XX wieku, „Wojna Revue”, 11.08.1017, https://magazyn.wp.pl/ artykul/slowa-ktore-niosly-smierc-kryptonimy-operacji-wojskowych-w-xxwieku (dostęp: 30.07.2018).

Debus Friedhelm, 2012, Namenkunde und Namengeschichte. Eine Einführung, Erich Schmidt, Berlin.

Duden. Deutsches Universalwörterbuch, 1996, Dudenverlag, Mannheim.

Eckrrammer Eva Martha, Thaler Verena, 2013, Die Ergonymie als namenkundliche Subdisziplin. Beobachtungen zur Terminologie und zum aktuellen Forschungsstand, w: tychże, red., Kontrastive Ergonymie. Romanistische Studien zu Produkt- und Warennamen, Frank \& Timme, Berlin, s. 7-53.

FleISCHER Wolfgang, 1992, Name und Text: ausgewählte Studien zur Onomastik und Stilistik. Zum 70. Geburtstag herausgegeben und eingeleitet von Irmhild Barz et al., Niemeyer Verlag, Tübingen.

Fleischer Wolfgang, BARZ Irmhild, 2007, Wortbildung der deutschen Gegenwartssprache, Niemeyer Verlag, Tübingen.

Grabias Stanisław, 1997, Język w zachowaniach społecznych, Wydawnictwo Uniwersytetu Marii Curie-Skłodowskiej, Lublin.

Guz Marzena, 2006, Verbalisierungen von naturbezogenen Substantiven im Deutschen und im Polnischen, w: J.F. Nosowicz, M. Pieklarz, red., Edukacja dla przyszłości, t. 3, Wydawnictwo Wyższej Szkoły Finansów i Zarządzania w Białymstoku, Białystok, s. 195-206.

Guz Marzena, 2014, Zur Struktur der Katzenrassennamen, „Rozprawy Komisji Językowej ŁTN", t. LX, s. 81-91.

Guz Marzena, 2018, Der polnische Wortschatz in der Seeschifffahrt der 1980erJahre, w: M. Lisiecka-Czop, K. Sztandarska, B. Utermöhlen, red., Sprachen in fach- und berufsbezogenen Kontexten. Theoretische und praktische Überlegungen, Verlag Dr. Kovač, Hamburg, s. 119-137.

HARnisch Rüdiger, NüBling Damaris, 2004, Namenkunde, w: G. Booij i in., red., Morphologie/Morhology. Ein internationales Handbuch zur Flexion und Wortbildung, t. 2, de Gruyter, Berlin, s. 1901-1909.

KauBE Jürgen, 2012, Diskursive Klingeltöne, w: J. Voss, M. Stolleis, red., Fachsprachen und Normalsprache, Wallstein, Göttingen, s. 105-114.

KempF Luise, 2016, Adjektivsuffixe in Konkurrenz. Wortbildungswandel vom Frühneuhochdeutschen zum Neuhochdeutschen, de Gruyter, Berlin-Boston. KoŁODZIEJEK Ewa, 1994, Gwara środowiskowa marynarzy na tle subkultury marynarskiej, Wydawnictwo Naukowe Uniwersytetu Szczecińskiego, Szczecin. 
KRAMER Undine, 2018, Maritimer Wortschatz in allgemeinen einsprachigen Wörterbüchern des Deutschen und im individualsprachlichen Goethe-Wörterbuch, w: M. Lisiecka-Czop, K. Sztandarska, B. Utermöhlen, red., Sprachen in fachund berufsbezogenen Kontexten. Theoretische und praktische Überlegungen, Verlag Dr. Kovač, Hamburg, s. 73-90.

Lesz-DuK Maria, 2017, Żywioły obecne w stownictwie żeglarskim, w: H. Kaczmarek, red., Żywioły w poznaniu. Konceptualizacja żywiołów. Wieloaspektowość badań - różnorodność rozwiązań, t. 2, Wydawnictwo im. Stanisława Podobińskiego Akademii im. Jana Długosza w Częstochowie, Częstochowa, s. $225-235$.

Linde-UsieKniewicz Jadwiga, red., 2007, Wielki stownik angielsko-polski, Wydawnictwo Naukowe PWN, Warszawa.

LipCZUK Ryszard, SzTANDARSKa Katarzyna, 2018, Maritimer Wortschatz in ausgewählten Wörterbüchern mit puristischen Zielen, w: M. Lisiecka-Czop, K. Sztandarska, B. Utermöhlen, red., Sprachen in fach- und berufsbezogenen Kontexten. Theoretische und praktische Überlegungen, Verlag Dr. Kovač, Hamburg, s. 103-118.

LisieCKA-Czop Magdalena, 2010, „Als die Seemannssprache noch romantisch war" - nautischer Wortschatz des 18. Jahrhunderts im Spiegel des Allgemeinen Wörterbuches der Marine (1793-1798) von Johann Hinrich Röding, „Studia Maritima”, t. XXIII, s. 41-60.

ŁUCZYŃSki Edward, 1986, Staropolskie słownictwo związane z żegluga. XV $i$ XVI w., Wydawnictwo Morskie, Gdańsk.

ŁuCZYŃSKI Edward, 1987, Polska terminologia morska I połowy XX wieku, Uniwersytet Gdański, Gdańsk.

Maritimes Wörterbuch zusammengestellt von Jürgen Gebauer und Egon Krenz, 1989, Militärverlag der Deutschen Demokratischen Republik, Berlin.

Maziarz Radosław, 2012, Morphologie, w: L. Wille, R. Maziarz, red., Einführung in die Sprachwissenschaft, Wydawnictwo Uniwersytetu Rzeszowskiego, Rzeszów s. 27-33.

Opitz Kurt, 1998, Die technische Fachsprache der Seefahrt, w: L. Hoffman, H. Kalverkämper, H.E. Wiegand, red., Fachsprachen. Languages for Special Purposes. Ein internationales Handbuch zur Fachsprachenforschung und Terminologiewissenschaft, t. 1, de Gruyter, New York-Berlin, s. 1211-1216. OżDŻYŃSKI Jan, 1989, Morska wspólnota kulturowa w świetle faktów językowych. Morfologia zapożyczeń w polskim słownictwie flisackim i żeglarskim, Wydawnictwo Naukowe Wyższej Szkoły Pedagogicznej, Kraków. 
PfeIfER Wolfgang, red., 1997, Etymologisches Wörterbuch des Deutschen, Deutscher Taschenbuch Verlag, München.

SchlaEfer Michael, 2009, Lexikologie und Lexikographie. Eine Einführung am Beispiel deutscher Wörterbücher, Erich Schmidt Verlag, Berlin.

SchмidT Wilhelm, 1984, Geschichte der deutschen Sprache, Verlag Volk und Wissen, Berlin.

Sors Agnieszka, 2013, Sposoby określania ruchu łodzi w socjolekcie żeglarskim, „Język w Komunikacji”, nr 3, s. 119-129.

Szczaus Agnieszka, 2018, Stowniczek żeglarski i słowniczek hydrograficzny w Nowych Atenach Benedykta Chmielowskiego (1745-1746), w: M. Lisiecka-Czop, K. Sztandarska, B. Utermöhlen, red., Sprachen in fach- und berufsbezogenen Kontexten. Theoretische und praktische Überlegungen, Verlag Dr. Kovač, Hamburg, s. 91-101.

Tadeusz Elżbieta, Laskowski Marek, 1994, Stereotype Zwillingsformeln im Deutschen, Wydawnictwa Szkolne i Pedagogiczne, Warszawa.

Webв Barbara, 2012, Stownik żeglarski: 10-języczny: polski, francuski, niemiecki, holenderski, angielski, hiszpański, włoski, portugalski, turecki, grecki, Oficyna Wydawnicza Alma-Press, Warszawa.

ZABRoCKI Ludwik, 1956, Zwiąki językowe niemiecko-pomorskie, w: Z. Stieber, red., Konferencja Pomorska (1954). Prace Językoznawcze, Państwowe Wydawnictwo Naukowe, Warszawa, s. 149-174.

https://sjp.pwn.pl/sjp/kryptonim;2565035.html (dostęp: 30.07.2018).

\title{
Marzena Guz
}

\section{NIEMIECKIE SŁOWNICTWO MARYNISTYCZNE W PUBLIKACJI MARITIMES WÖRTERBUCH JÜRGENA GEBAUERA I EGONA KRENZA. WYBRANE ZAGADNIENIA}

\begin{abstract}
Streszczenie
Celem niniejszego artykułu jest analiza językowa słownictwa marynistycznego ze słownika Maritimes Wörterbuch zusammengestellt von Jürgen Gebauer und Egon Krenz (1989). W opracowaniu omówiono zagadnienia morfologiczne oraz problem składni. Materiał badawczy został zanalizowany także pod kątem onomastyki, poruszono również kwestie zapożyczeń oraz żargonu żeglarskiego. W słowniku, podobnie jak w całym języku niemieckim, występuje bogactwo złożeń. Uwagę przyciagga bogaty repertuar przydawek rzeczownikowych. W źródle, o którym mowa, odnotować można eponimy, kryptonimy, nazwy wydarzeń historycznych oraz ergonimy (nazwy instytucji). Żargon marynarski nieznacznie nacechowany jest ekspresywnością.
\end{abstract}




\title{
GERMAN MARITIME VOCABULARY IN THE PUBLICATION, MARITIMES WÖRTERBUCH BY JÜRGEN GEBAUER AND EGON KRENZ. SELECTED QUESTIONS
}

\begin{abstract}
Summary
The aim of this article is to analyse maritime vocabulary in the publication Maritimes Wörterbuch zusammengestellt von Jürgen Gebauer und Egon Krenz (1989). Morphological issues and syntax problems will be discussed. The research material will also be analysed in terms of onomastics and the issue of borrowings and sailing jargon will be discussed. The dictionary, and the German language in general are rich in complexities. The rich repertoire of noun additives attracts attention. The source in question includes eponyms, cryptonyms, names of historical events and ergonyms (names of institutions). Naval jargon is not very expressive.
\end{abstract}

